\title{
Integrasi Pendidikan Anti Narkoba dalam Pendidikan Agama Islam dan Budi Pekerti Kurikulum 2013
}

\author{
Imam Machali \\ UIN Sunan Kalijaga Yogyakarta \\ E-mail: imam.machali@uin-suka.ac.id
}

\begin{abstract}
This article describe the antidrug education and the integration of anti-drug education in the curriculum of Islamic religious and moral education of the year 2013. The results showed that the antidrug education began in elementary, junior and senior high school that includes knowledge about drugs and the dangers, increase self-esteem, and the formation of assertiveness. Integration of anti-drug education in the curriculum of Islamic religious education and moral includes three aspects, namely: knowledge (cognitive), attitudes and behaviours (affective), and skills (psychomotor). Implementation of antidrug education at school level using integrative-inclusive strategy. Anti-drug education learning management can be integrated in all subjects, both religious and secular.
\end{abstract}

Keyword: antidrug education, curriculum 2013

\begin{abstract}
Abstrak
Artikel ini bertujuan mendeskripsikan pendidikan anti narkoba dan integrasi pendidikan anti narkoba pada kurikulum Pendidikan Agama Islam dan Budi Pekerti Tahun 2013. Hasil penelitian menunjukkan bahwa pendidikan antinarkoba sudah dimulai sejak SD, SMP dan SMA yang mencakup pengetahuan tentang narkoba dan bahayanya, peningkatan harga diri, dan pembentukan asertasi. Integrasi pendidikan anti narkoba pada kurikulum Pendidikan Agama Islam dan Budi Pekerti mencakup tiga domain, yakni domain pengetahuan (kognitif), sikap dan perilaku (afeksi), dan keterampilan (psikomotorik). Implementasi pendidikan antinarkoba di jenjang sekolah menggunakan strategi integratif-inklusif. Manajemen pembelajaran pendidikan antinarkoba dapat diintegrasikan di semua mata pelajaran, baik agama maupun umum.
\end{abstract}

Kata kunci: pendidikan antinarkoba, kurikulum 2013 


\section{A. Pendahuluan}

Ancaman bahaya penyalahgunaan narkoba semakin meningkat. Sasarannya adalah generasi muda yang merupakan tulang punggung pembangunan bangsa. Berdasarkan hasil survei Badan Narkotika Nasional (BNN) diperoleh data bahwa rata-rata usia pertama kali menggunakan narkoba terjadi pada usia 12-15 tahun. Hasil penelitian BNN bekerja sama dengan Pusat Studi Kesehatan Universitas Indonesia menunjukkan bahwa pada tahun 2008 angka prevalensi penyalahgunaan narkoba mencapai 1,99 persen atau setara dengan 3,6 juta jiwa sedangkan pada 2011 mengalami peningkatan menjadi 2,2 persen atau setara dengan 4,2 juta jiwa.

Penyalahgunaan narkotika di Indonesia dari tahun ke tahun terus menunjukkan peningkatan yang signifikan. Berdasarkan data hasil riset BNN dengan Universitas Indonesia, angka itu mencapai 2,32 persen sepanjang tahun 2012. Angka itu diperkirakan akan meningkat menjadi 2,8 persen pada tahun 2015 jika terus dibiarkan. "Diperkirakan angka prevalensi itu di tahun 2015 menjadi 2,8 persen atau setara dengan 5 juta jiwa orang Indonesia. ${ }^{1}$. Dugaan penyalahgunaan narkoba diprediksi sebesar 5,6 juta jiwa. Sedangkan dampak kematian atas penyalahgunaan narkoba sebesar 50 orang per hari. Tersangka kasus narkoba pada rentang tahun 2010 sampai dengan tahun 2014 sebanyak 134.117 orang. ${ }^{2}$

Salah satu langkah yang efektif dalam mengerem laju penyalahgunaan narkoba adalah dengan pendidikan. Pada Tahun 2013, pemerintah memasukkan pendidikan anti narkoba dalam materi pembelajaran di kurikulum 2013. Pendidikan anti narkoba dimasukkan dalam pendidikan ekstrakurikuler. Dimasukkannya pendidikan anti narkoba dalam kurikulum dimaksudkan untuk mengantisipasi penyalahgunaan narkoba sejak dini.

Keputusan pemerintah memasukkan pendidikan anti narkoba merupakan respons atas berbagai kritik terhadap dunia pendidikan selama ini. Pendidikan dianggap tidak mampu melahirkan lulusan yang berkualitas; manusia Indonesia seutuhnya seperti cita-cita luhur bangsa dan yang diamanatkan oleh Undang-undang Pendidikan. Permasalahan kegagalan dunia pendidikan di

\footnotetext{
${ }^{1}$ Suara Karya, Jum'at 12 April 2013

${ }^{2}$ Jawa Post, Minggu 8 Februari 2015
} 
Indonesia-termasuk pendidikan agama - disebabkan dunia pendidikan selama ini hanya membina kecerdasan intelektual, wawasan dan keterampilan semata, tanpa diimbangi dengan pembinaan kecerdasan emosional.

Kurikulum 2013 bertema "Insan Indonesia yang Produktif, Kreatif, Inovatif dan Afektif", dirancang untuk mengintegrasikan ilmu pengetahuan yang dimiliki peserta didik dalam sikap, perilaku dan mental spiritual kehidupan yang diimplementasikan dalam keterampilan (skill) peserta didik. Lebih-lebih bagi pendidikan agama Islam sebagai imbas dari pola pendidikan selama ini yang dipandang lebih mengutamakan kemampuan berpikir (kognitif) daripada afektif dan psikomotor peserta didik.

Dalam Kurikulum 2013 terjadi perubahan istilah Standar Kompetensi (SK) setiap aspek dalam PAI (Al-Qur'an, Aqidah, Akhlaq, Fiqih, SKI) menjadi Kempetensi Inti (KI), yaitu Sikap Spiritual (KI 1), Sikap Sosial (Afektif [KI 2]), Pengetahuan (Kognitif [KI 3]), dan Keterampilan (Psikomotorik [KI 4]).

Perubahan ini merupakan harapan mulia dari pemerintah yang menginginkan PAI tidak hanya memuat teori-teori, akan tapi mendorong siswa agar memiliki keterampilan (skill) dan juga berakhlak mulia. Hal ini terlihat dari adanya penambahan kata "Budi Pekerti" dalam nama mata pelajaran PAI, yang walaupun tanpa penambahan kata tersebut juga sebenarnya Agama Islam sudah menjelaskan dan mengajarkan bagaimana setiap orang berbudi pekerti atau berakhlak mulia karimah.

Secara hierarkis, Standar Isi Kurikulum PAI 2013 dijabarkan dalam bentuk Kompetensi Inti (KI) dan Kompetensi Dasar (KD) serta Tujuan Pembelajaran yang terdiri dari empat kompetensi utama yaitu: Kompetensi Inti Satu/ KI-1 (Sikap Spiritual): Menghargai dan menghayati ajaran agama yang dianutnya, Kompetensi Inti dua/KI-2 (Sikap Sosial): Menghargai dan menghayati perilaku jujur, disiplin, tanggung jawab, peduli (toleransi, gotong royong), santun, percaya diri dalam berinteraksi secara efektif dengan lingkungan sosial dan alam dalam jangkauan pergaulan dan keberadaannya. Kompetensi Inti Tiga/KI-3 (Pengetahuan): Memahami pengetahuan (faktual, konseptual dan prosedural) berdasarkan rasa ingin tahunya tentang ilmu pengetahuan, teknologi, seni, budaya terkait fenomena dan kejadian tampak mata. Kompetensi Inti Empat/KI-4 (Keterampilan): Mencoba, mengolah, dan menyaji dalam ranah 
konkret (menggunakan, mengurai, merangkai, memodifikasi, dan membuat) dan ranah abstrak (menulis, membaca, menghitung, menggambar, dan mengarang) sesuai dengan yang dipelajari di sekolah dan sumber lain yang sama dalam sudut pandang/teori yang kemudian dijabarkan ke dalam Kompetensi Dasar (KD). ${ }^{3}$

Artikel ini bertujuan mendeskripsikan integrasi pendidikan anti narkoba dalam kurikulum 2013 mata pelajaran Pendidikan Agama Islam dan Budi Pekerti. Degan menggunakan analisis isi (content analysis) pertanyaan yang akan dijawab dalam artikel ini adalah bagaimana materi pendidikan anti narkoba dan integrasi pendidikan anti narkoba pada kurikulum Pendidikan Agama Islam dan Budi Pekerti Tahun 2013.

\section{B. Pendidikan Antinarkoba}

Narkoba adalah singkatan dari narkotika dan obat/bahan berbahaya. Selain narkoba, istilah lain yang diperkenalkan khususnya oleh Departemen Kesehatan Republik Indonesia adalah Napza yang merupakan singkatan dari dari Narkotika, Psikotropika dan Zat Adiktif. Sedangkan pendidikan Antinarkoba adalah usaha sadar dan terencana untuk mewujudkan suasana belajar dan proses pembelajaran agar peserta didik secara aktif mengembangkan potensi dirinya untuk memiliki kekuatan spiritual keagamaan, pengendalian diri, menghindari, menolak, melawan, dan mengampanyekan anti narkoba sehingga bahaya narkoba tidak meluas ke segenap masyarakat.

Pendidikan Antinarkoba dilakukan secara terpadu dengan melibatkan setiap unsur masyarakat yang terkait dan peduli terhadap usaha preventif bahaya narkoba. Terdapat tiga prinsip yang melandasi Pendidikan Antinarkoba. Pertama, terpadu yaitu kerja sama erat antara pihak sekolah dengan masyarakat. Tujuannya agar semua pihak memahami akan bahaya narkoba dan memperkuat tekad agar orang yang belum terkena jangan sampai tertular oleh kecanduan narkoba. Kedua profesional artinya harus disusun progarm-program Pendidikan Antinarkoba yang sistematis dan sesuai perkembangan peserta didik. Ketiga, kebutuhan artinya program Pendidikan Antinarkoba hendaknya berdasarkan kebutuhan masyarakat, terutama generasi muda dan keluarga.

${ }^{3}$ Kemendikbud, Kurikulum 2013, (Jakarta: Kementerian Pendidikan dan Kebudayaan RI, 2013). 
Sekolah memegang peranan penting dalam penanggulangan narkoba, karena sekolah merupakan tempat berkumpulnya anakanak muda yang sering dijadikan sasaran narkoba. Data Bareskrim Mabes Polri menyebutkan tersangka penyalah guna narkoba di lingkungan SD tahun 2003 berjumlah 88 orang dan meningkat tahun 2004 menjadi 407 orang. Di lingkungan SMP tahun 2003 berjumlah 632 orang dan tahun 2004 meningkat 968 orang, dan di lingkungan SMA tahun 2003 berjumlah 887 orang dan tahun 2004 meningkat berjumlah menjadi 1511 orang.

Sekolah sebagai institusi dan lembaga pendidikan memiliki empat komponen penting. Pertama, sekolah menyediakan kerangka kerja bagi perencanaan, pengimplementasian dan pengevaluasian dalam upaya pencegahan dan pengurangan penyalahgunaan drug (termasuk alkohol dan rokok). Kedua, sekolah menyediakan lingkungan fisik dan sosial bagi pengembangan kesehatan siswa berkaitan dengan tujuan pendidikan yang ingin dicapai sesuai dengan jenjang pendidikan. Ketiga, membantu siswa berperilaku (skills-based drug education) dan menciptakan kondisi yang sehat bagi siswa. Keempat, Sekolah berperan dalam membentuk pengetahuan, sikap dan keterampilan yang diperlukan remaja nantinya dalam memilih dan mengambil keputusan untuk tidak menggunakan drug.

Salah satu indikasi suatu sekolah telah tumbuh religiositas peserta didiknya antara lain adalah terdapatnya perilaku dan tindakan yang mencerminkan pada anti narkoba. Sebab anti narkoba adalah keyakinan yang membuat seseorang bertindak atas dasar. Sedangkan Djahiri mendefinisikan anti narkoba sebagai harga yang diberikan oleh seseorang atau sekelompok orang terhadap sesuatu (material-immaterial, personal, kondisional) atau harga yang dibawakan/tersirat atau menjadi jati diri dari sesuatu.

Pencegahan berbasis sekolah (school based prevention) lebih mudah dilaksanakan karena sekolah terstruktur sehingga dapat diadakan pengawasan secara komprehensif dan terpadu. Pelaksanaan pendidikan pencegahan di sekolah dimasukkan dalam kegiatan ekstrakurikuler dan pengembangan diri ataupun disisipkan pada pelajaran agama dan budi pekerti yang bertujuan untuk mensosialisasikan kebijakan penanggulangan dan bahaya penyalahgunaan narkoba. Dalam mengimplementasikan konsep integrasi pendidikan anti narkoba dalam pembelajaran di sekolah, kita dapat merujuk referensi yang ditawarkan Bagir, dkk. yang 
membaginya ke dalam empat tataran implementasi, yaitu tataran konseptual, institusional, operasional, dan arsitektural. Dalam tataran konseptual, integrasi pendidikan anti narkoba dapat diwujudkan melalui perumusan visi, misi, tujuan dan program sekolah (rencana strategis sekolah).

Adapun secara institusional, integrasi dapat diwujudkan melalui pembentukan institution culture yang mencerminkan paduan antara anti narkoba dan pembelajaran. Dalam tataran operasional, rancangan kurikulum dan esktrakurikuler harus diramu sedemikian rupa sehingga nilai-nilai fundamental agama dan ilmu terpadu secara koheren. Sementara secara arsitektural, integrasi dapat diwujudkan melalui pembentukan lingkungan fisik yang berbasis IPTEK (Ilmu Pengetahuan dan Teknologi) dan IMTAK (Iman dan Takwa). Seperti, sarana ibadah yang lengkap, sarana laboratorium yang memadai, serta perpustakaan yang menyediakan buku-buku agama dan ilmu umum secara lengkap.

\section{Kurikulum PAI dan Budi Pekerti $2013^{4}$}

Istilah kurikulum mempunyai pengertian yang cukup beragam mulai dari pengertian yang sempit hingga yang sangat luas. Pengertian kurikulum secara sempit seperti yang dikemukakan oleh William B. Ragan yang dikutip oleh Hendyat Soetopo dan Wasty Soemanto: "Traditionally, the curriculum has meant the Subject taugth in school, or course of study". ${ }^{5}$ Senada dengan definisi ini, Carter V. Good menyatakan: "Curriculum as a systematic group of courses or sequences of subject required for graduation or certification in a major field of study, for example, social studies curriculum, physical education curriculum...". 6 Ronald C. Doll mendefinisikan: "The curriculum of the school is the formal and informal content and process by which learner gain knowledge understanding develop skills and alter attitude

${ }^{4}$ Eksplorasi mengenai kurikulum ini diambilkan dari naskah penulis berjudul "Kebijakan Perubahan Kurikulum 2013 dalam Menyongsong Indonesia Emas Tahun 2045" dalam Jurnal Pendidikan Islam, (volume III, No 1/Juni 2014), hlm. 71-94.

5 Hendyat Soetopo dan Wasty Soemanto, Pembinaan dan Pengembangan Kurikulum, (Jakarta: Bina Aksara, 1986), hlm. 12.

${ }^{6}$ Carter V. Good, ed., Dictionary of Education, Third edition, (New York: McGraw-Hill, 1973), hlm. 157. 
appreciations and values under the auspice of that school". ${ }^{7}$ Beberapa pengertian kurikulum ini merupakan pengertian yang sempit dan tradisional. Di sini, kurikulum sekedar memuat dan dibatasi pada sejumlah mata pelajaran yang diberikan guru atau sekolah kepada peserta didik guna mendapatkan ijazah atau sertifikat.

Pengertian kurikulum yang sangat luas dikemukakan oleh Hollis L. Caswell dan Doak S. Campbell yang memandang kurikulum bukan sebagai sekelompok mata pelajaran, tetapi kurikulum merupakan semua pengalaman yang diharapkan dimiliki peserta didik di bawah bimbingan para guru "curriculum not as a group of courses but as all the experiences children have under the guidance of teachers". ${ }^{8}$ Sejalan dengan pengertian ini, J. Galen Saylor, William M. Alexander dan Arthur J. Lewis juga mengungkapkan pengertian kurikulum yang dikutip oleh Peter F. Oliva "We define curriculum as a plan for providing sets of learning opportunities for persons to be educated". 9

Demikian pula, disampaikan oleh Harold B, Albertycs yang memandang kurikulum sebagai all of the activities that are provided for students by the school. ${ }^{10}$ Selain itu, Alice Miel juga mengemukakan, yang dikutip Nasution bahwa kurikulum meliputi keadaan gedung, suasana sekolah, keinginan, keyakinan, pengetahuan dan sikap orang-orang yang melayani dan dilayani sekolah, yakni anak didik, masyarakat, para pendidik dan personalia - termasuk penjaga sekolah, pegawai administrasi, dan orang lainnya yang ada hubungannya dengan murid-murid. ${ }^{11}$

Pengertian kurikulum sebagaimana di atas mencakup semua pengalaman yang diharapkan dikuasai peserta didik di bawah bimbingan para guru. Pengalaman ini bisa bersifat intrakurikuler, kokurikuler maupun ekstra kurikuler, baik pengalaman di dalam maupun di luar kelas. Dengan demikian dapat dipahami bahwa kurikulum mencakup pengertian yang sangat luas meliputi apa

7 Ronald C. Doll, Curriculum Improvemet Decision Making And Process, (Boston: Nallyn Bacon, 1996), hlm. 15.

${ }^{8}$ Peter F. Oliva, Developing the Curriculum, (New York: HarperCollins Publisher, 1992), hlm. 6

${ }^{9}$ Peter F. Oliva, Developing the Curriculum..., hlm. 6 lihat juga S. Nasution, Pengembangan Kurikulum, (Bandung: Citra Aditya Bakti, 2003), hal. 4

${ }^{10}$ S. Nasution, Pengembangan Kurikulum,... hlm. 5

${ }^{11}$ S. Nasution, Pengembangan Kurikulum,... hlm. 6 
yang disebut dengan kurikulum potensial, kurikulum aktual, dan kurikulum tersembunyi atau hidden curriculum. Kurikulum tersembunyi adalah hal atau kegiatan yang terjadi di sekolah dan ikut mempengaruhi perkembangan peserta didik, namun tidak diprogramkan dalam kurikulum potensial. Dalam pengertian lain kurikulum tersembunyi adalah hasil; dari suatu proses pendidikan yang tidak direncanakan. Artinya, perilaku yang muncul dari luar tujuan yang dideskripsikan oleh guru. ${ }^{12}$

Terdapat tiga hal dalam pembahasan kurikulum dan pengembangannya yaitu pertama kurikulum sebagai rencana (as a plan) yang menjadi pedoman (guideline) dalam mencapai tujuan yang akan dicapai. Kedua, kurikulum sebagai materi atau isi (curriculum as a content) yang akan disampaikan kepada peserta didik, dan ketiga, dengan cara apa dan bagaimana kurikulum disampaikan. Ketiga hal tersebut adalah satu kesatuan dan bersinergi dalam rangka mencapai tujuan pendidikan yang diinginkan.

Oleh karena itu, pengembangan kurikulum dapat dipahami sebagai sebuah proses penyusunan rencana tentang isi atau materi pelajaran yang harus dipelajari dan bagaimana cara mempelajarinya. Dalam hal ini pengembangan kurikulum adalah sebuah proses yang terus menerus (continue), dinamis (dynamic), dan kontekstual (contextual). ${ }^{13}$

Kurikulum memiliki fungsi dan peran yang sangat penting dan strategis. Meskipun bukan satu-satunya faktor utama keberhasilan proses pendidikan, kurikulum menjadi petunjuk dan arah terhadap keberhasilan pendidikan. Kurikulum menjadi penuntun (guide) para pelaksana pendidikan (pendidik dan tenaga kependidikan) untuk mengembangkan kreativitas dan kemampuannya dalam mengembangkan dan menjabarkan berbagai materi dan perangkat pembelajaran. Oleh karena itu, pendidik dan tenaga kependidikan yang baik adalah yang mampu memahami kurikulum dan mengimplementasikannya pada proses pembelajaran.

Perubahan, pengembangan, dan perbaikan terus dilakukan, seiring dengan tuntutan dan perubahan zaman dalam berbagai

12 Wina Sanjaya, Kurikulum dan Pembelajaran. (Jakarta: Kencana, 2008), hlm. 25

${ }^{13}$ Imam Machali, "Kurikulum Dimensi Kecerdasan Majemuk (Multiple Intellegences) dalam Kurikulum 2013”, Insania, (Vol. 19 No. 1 Juni 2014), hlm. 5 
aspek kehidupan di era globalisasi. Pergulatan perubahan kurikulum sangat nampak pada tahun 1975, 1984, 1994, banyak menuai berbagai kritik karena dinilai terlalu banyak mata pelajaran dan terlalu padat materi. Padatnya kurikulum berdampak pada padatnya informasi dalam buku teks.

Pada tahun 1975, pembaruan kurikulum didasarkan pada perkembangan ilmu pengetahuan dan teknologi pada saat itu, sehingga pembaruan tersebut menghasilkan kurikulum 1975 yang sangat sarat beban dan sarat muatan, bahan-bahan yang berat dan sangat berorientasi pada sasaran hasil. Hal ini dipengaruhi oleh paradigma kerangka instruksional, yang sangat mendasarkan diri pada sasaran, instruksi dan evaluasi. Pembaharuan Kurikulum tahun 1984 berusaha menyederhanakan itu semua. Pembaruan tahun 1994 memadukan teknologi melalui pemecahan masalah, berpikir kritis, dan keterampilan bertanya dalam praktik di kelas. ${ }^{14}$

Koreksi, evaluasi dan kritik terhadap kurikulum 1994 terus dilakukan. Kemudian pemerintah melakukan pembaruan dengan diberlakukannya kurikulum 2004 yang diharapkan sebagai kurikulum yang menerapkan kompetensi sebagai tujuan akhir pembelajaran. Kurikulum 2004 kemudian dikenal dengan Competence Based Curriculum atau Kurikulum Berbasis Kompetensi (KBK). ${ }^{15}$ Belum lagi KBK diterapkan secara menyeluruh, muncul kemudian Kurikulum Tingkat Satuan Pendidikan (KTSP) yang

14 Direktorat Jenderal Pendidikan Islam, Direktorat Pendidikan Agama Islam, Pedoman Umum Implementasi Kurikulum 2013, (Jakarta; Kementerian Agama RI, 2013), hlm. 1

15 Kompetensi secara bahasa berasal dari kata "competence" yang berarti "kecakapan", "kemampuan", "keahlian". Spencer mendefinisikan kompetensi sebagai Competency is an underlying characteristic of an individual that is causally related to criterion-referenced effective and/or superior performance ion a job or situation. Tiga kata kunci dalam definisi tersebut yaitu underlying characteristic, causally related, dan criterionreferenced. Underlying characteristic means the competency is a fairly deep and enduring part of a person's personality and can predict behaviour in a wide variety of situations and job tasks. Causally related means that a competence causes or predicts behaviour and performance. Dan criterionreferenced means that competency actually predicts who does something well or poorly, as measured on a specific criterion or standard. Dalam sebuah kompetensi, menurut Spencer setidaknya mempunyai lima krakteristik yaitu motif, traits, konsep diri (self-concept), pengetahuan (knowledge) dan keterampilan (skill). Lihat Lyle M. Spencer, Competence at Work: Models for Superior Performance, (Canada: John wiley \& Son, 1993), hlm. 9 
merupakan penyempurnaan kurikulum KBK yang dianggap lebih mampu menjawab tantangan yang lebih jelas dan memberikan muatan lokal kepada daerah atau lembaga pendidikan.

Walaupun perubahan dan pembaruan kurikulum terus dilakukan dengan melibatkan berbagai unsur yang berkompeten, kritik dan berbagai keluhan terus diarahkan terhadap pemerintahKemendikbud - sebagai lembaga penanggung jawab bidang pendidikan nasional. KTSP dinilai masih memberatkan pada peserta didik, baik dari substansi maupun metodologinya. Pelajaran yang diterapkan di satuan pendidikan terutama di jenjang pendidikan dasar, terlalu padat dan tumpang tindih. Berdasarkan hasil kajian, penelitian, dan evaluasi menyeluruh kemudian KTSP disempurnakan dalam kurikulum baru yang dikenal dengan kurikulum 2013.

Dinamakan dengan kurikulum 2013, sebab kebijakan implementasi kurikulum ini dilaksanakan pada tahun 2013. Berbagai kebijakan pendukung implementasi kurikulum ini dikeluarkan pada tahun 2013 seperti PP Nomor 32 Tahun 2013 tentang Perubahan atas Peraturan Pemerintah Nomor 19 Tahun 2005 Tentang Standar Nasional Pendidikan, Permendikbud No 54 Tahun 2013 tentang SKL, 65 tahun 2013 tentang standar Proses, dan lain-lain. Bahkan pada tahun 2014 Kementerian Pendidikan dan Kebudayaan juga telah mengeluarkan peraturan pendukung, dan penyempurnaan implementasi kurikulum 2013 seperti Permendikbud Nomor 57, 58, 59 Tahun 2014 tentang Kurikulum 2013 SD/MI, SMP/MTs, SMA/MA, dan lain-lain.

Kehadiran kurikulum 2013 diharapkan mampu melengkapi kekurangan-kekurangan yang ada pada kurikulum sebelumnya. Kurikulum 2013 disusun dengan mengembangkan dan memperkuat sikap, pengetahuan, dan keterampilan secara berimbang. Penekanan pembelajaran diarahkan pada penguasaan pengetahuan dan keterampilan yang dapat mengembangkan sikap spiritual dan sosial sesuai dengan karakteristik Pendidikan Agama Islam dan Budi Pekerti diharapkan akan menumbuhkan budaya keagamaan (religious culture) di sekolah.

Titik tekan pengembangan Kurikulum 2013 ini adalah penyempurnaan pola pikir, penguatan tata kelola kurikulum, pendalaman dan perluasan materi, penguatan proses pembelajaran, dan penyesuaian beban belajar agar dapat menjamin kesesuaian antara apa yang diinginkan dengan apa yang dihasilkan. Oleh 
karena itu, implementasi Kurikulum 2013 diyakini sebagai langkah strategis dalam menyiapkan dan menghadapi tantangan globalisasi dan tuntutan masyarakat Indonesia masa depan.

Kompetensi masa depan yang diperlukan dalam menghadapi arus globalisasi antara lain berkaitan dengan kemampuan berkomunikasi, kemampuan berpikir jernih dan kritis, kemampuan mempertimbangkan segi moral suatu permasalahan, kemampuan menjadi warga Negara yang bertanggung jawab, kemampuan mencoba untuk mengerti dan toleran terhadap pandangan yang berbeda, dan kemampuan hidup dalam masyarakat yang mengglobal. Di samping itu, generasi Indonesia juga harus memiliki minat luas dalam kehidupan, memiliki kesiapan untuk bekerja, memiliki kecerdasan sesuai dengan bakat/minatnya, dan memiliki rasa tanggung jawab terhadap lingkungan. Dengan berbagai tantangan masa depan inilah kebijakan kurikulum 2013 ditetapkan.

Kurikulum PAI dan Budi Pekerti dalam kurikulum 2013 mencakup usaha untuk mewujudkan keharmonisan, keserasian, kesesuaian, dan keseimbangan antara hubungan manusia dengan Sang Pencipta (Allah swt), manusia dengan manusia, hubungan manusia dengan makhluk lain dan lingkungan alam, hubungan manusia dengan dirinya sendiri (berakhlak dengan diri sendiri). Keempat hubungan tersebut, tercakup dalam kurikulum PAI yang tersusun dalam beberapa mata pelajaran, yaitu, mata pelajaran akidah akhlak, mata pelajaran ibadah syariah (fiqh), mata pelajaran al-Qur'an Hadis, Mata pelajaran Sejarah dan Kebudayaan Islam (SKI), dan mata pelajaran Bahasa Arab.

Mata-mata pelajaran tersebut merupakan scope atau ruang lingkup kurikulum PAI yang disajikan pada sekolah-sekolah yang berciri khas agama Islam atau madrasah, sementara ruang lingkup kurikulum PAI pada sekolah-sekolah umum adalah mata pelajaran pendidikan agama Islam yang bentuk kurikulumnya broad field atau in one system.

\section{Pendidikan Antinarkoba dalam KI, KD PAI dan Budi Pekerti Kurikulum 2013}

Materi Pendidikan Agama Islam dan Budi Pekerti dalam KI dan KD PAI kurikulum 2013 menunjukkan bahwa pendidikan antinarkoba sudah dimulai sejak SD. Bila diperhatikan metode pendidikan antinarkoba yang berisi tentang tiga hal yaitu: 
pengetahuan tentang narkoba dan bahayanya, peningkatan harga diri, dan pembentukan asertasi, maka kompetensi inti dan kompetensi dasar dari jenjang SD hingga SMA telah memuat hal tersebut. Pada jenjang SD, pendidikan antinarkoba ditekankan pada ranah afektif; pembentukan sikap peserta didik sehingga mampu menghindari narkoba.

Materi PAI yang tercermin pada Kompetensi Inti dan Kompetensi Dasar pada SD lebih menekankan pada pembentukan sikap dan peningkatan harga diri siswa, ataupun pembentukan asertasi. Materi tentang pengetahuan anti narkoba dan bahayanya belum secara eksplisit termuat dalam KI dan KD PAI SD. Hal tersebut karena ada kekhawatiran bila dalam pembelajaran, guru kurang menguasai dalam penyampaiannya maka anak akan tertarik untuk mencoba narkoba. Namun materi yang terkait dalam KI dan KD mulai dari kelas 1 hingga kelas 6 sudah menekankan pentingnya perilaku bersih dan sehat sebagai langkah pertama pendidikan antinarkoba.

Pada jenjang SMP pendidikan anti narkoba telah tertuang dalam materi khusus pada, yakni dalam Kompetensi Inti (KI) dan Kompetensi Dasar (KD) pada kelas VIII, meliputi materi alQur'an dan hadis berkenaan dengan bahaya dan larangan narkoba yang merupakan dasar hukum dalam tindakan. Dalil-dalil pada alQur'an dan hadis tersebut kemudian dikoneksikan dengan berbagai hal seputar narkoba dan bahayanya.

Selain itu, pembentukan sikap dan mental, serta peningkatan harga diri dan asertasi sebagai langkah dalam menanggulangi narkoba baik untuk membentengi diri dari pengaruh narkoba maupun amar ma'rúf kepada sesama teman juga begitu kuat ditanamkan pada kurikulum 2013 ini. Hal tersebut terlihat dari berbagai KD yang ada pada kelas VII s/d kelas IX kurikulum 2013 PAI SMP.

Sedangkan, pada pada KI dan KD SMA yang secara spesifik terkait dengan pendidikan antinarkoba terdapat dalam KD kelas IX antara lain;

1. Menunjukkan perilaku kontrol diri (mujahadah al-nafs), prasangka baik (husn al-žann), dan persaudaraan (ukhuwwah) sebagai implementasi dari pemahaman Q.S. Al-Anfāl/8: 72; al-Ḥujurāt/49: 12 dan 10 serta hadis yang terkait. 
2. Menunjukkan perilaku menghindarkan diri dari pergaulan bebas dan perbuatan zina sebagai implementasi dari pemahaman Q.S. al-Isrā'/17: 32, dan al-Nūr/24: 2, serta hadits yang terkait.

3. Memahami dan menganalisis Q.S. al-Anfāi/8: 72; alHujurāt/49: 12; dan al-Ḥujurāt/49: 10; serta hadits tentang kontrol diri (mujahadah al-nafs), prasangka baik (husn alzann), dan persaudaraan (ukhuwah).

\section{E. Analisis Pendidikan Antinarkoba dalam Buku Ajar PAI dan BP Kurikulum 2013}

Analisis pendidikan antinarkoba dalam buku ajar PAI dan Budi Pekerti kurikulum 2013 dalam penelitian ini lebih difokuskan pada materi yang secara eksplisit menerangkan tentang narkoba yaitu pada kelas VIII SMP. Hal ini penulis lakukan untuk menguji apakah materi pembelajaran dalam buku ajar tersebut khususnya pada buku siswa mampu memberikan pendidikan antinarkoba yang komprehensif, sistematis, rasional, dan mampu menyentuh perasaan dan menanamkan keyakinan yang kuat untuk menghindarkan dari narkoba. Sebaliknya, materi pendidikan antinarkoba yang terdapat pada buku ajar hanya mengedapankan sisi kognitif semata tanpa menyentuh aspek afektif dan keterampilan sebagai satu kesatuan dalam kurikulum 2013.

Materi pendidikan antinarkoba dalam kurikulum 2013 pada buku ajar SMP kelas 8 terdapat pada 3 Bab, yaitu Bab 8 dengan tema "Mengonsumsi Makanan dan minuman yang halal dan menjauhi yang haram", Bab 10 dengan tema "Hidup sehat dengan makanan dan minuman yang halal serta bergizi”, serta Bab 11 dengan tema "menghindari minuman keras, judi dan Pertengkaran".

Analisis pada Buku PAI dan Budi Pekerti Kurikulum 2013khususnya pada bab 8, bab 10 dan Bab 11 kelas VIII SMP/MTsmenunjukkan bahwa ulasan cukup lengkap dan komprehensif tentang Pendidikan antinarkoba. Pendidikan antinarkoba tidak hanya merupakan sebuah pengetahuan semata, namun dimulai dengan "renungan" dalam menumbuhkembangkan kesadaran peserta didik dimulai dengan dasar rasional dikaitkan "dialog islami” yang merupakan realitas sehari-hari yang dihadapi.

Begitu pula, dalil naqli ayat al Qur'an maupun hadis yang semakin memperkuat. Kemudian aktivitas siswa, refleksi akhlak 
mulia dan kisah teladan, dan ditutup interaksi antara guru dan orang tua siswa. Jika diimplementasikan secara baik, maka tujuan pendidikan antinarkoba, tidak hanya menekankan pada pengetahuan. Namun, akan tercapai sikap asertif.

\section{F. Integrasi Pendidikan Anti narkoba dalam PAI dan BP Kurikulum 2013}

Secara umum tujuan pendidikan antinarkoba adalah (1) pembentukan pengetahuan dan pemahaman mengenai bentuk narkoba dan aspek-aspeknya; (2) pengubahan persepsi dan sikap terhadap narkoba; dan (3) pembentukan keterampilan dan kecakapan baru yang ditujukan untuk melawan narkoba. Sedangkan manfaat jangka panjangnya adalah menyumbang pada keberlangsungan sistem integrasi nasional dan program antinarkoba pada diri peserta didik yang kelak akan menjalankan amanah di dalam sendi-sendi kehidupan.

Pendidikan antinarkoba yang dimaksud dalam penelitian ini adalah program pendidikan antinarkoba yang secara konsepsional memungkinkan disisipkan pada mata pelajaran yang sudah ada di sekolah dalam bentuk perluasan tema yang sudah ada dalam kurikulum dengan menggunakan pendekatan kontekstual pada pembelajaran antinarkoba. Pilihan ini digunakan oleh karena pertimbangan agar tidak menambah beban kurikulum dan jam belajar siswa. Pada aspek lain, pendidikan antinarkoba dapat juga diimplementasikan dalam bentuk mata pelajaran untuk kegiatan ekstra kurikuler siswa ataupun muatan lokal (institusional).

Ada dua model yang dapat dilakukan oleh sekolah untuk berpartisipasi dalam gerakan pemberantasan narkoba. Pertama, proses pendidikan harus menumbuhkan kepedulian sosialnormatif, membangun penalaran obyektif, dan mengembangkan perspektif universal pada individu. Kedua, pendidikan harus mengarah pada penyemaian strategis, yaitu kualitas pribadi individu yang konsekuen dan kokoh dalam keterlibatan peran sosial.

Dalam pendidikan antinarkoba harus mengintegrasikan tiga domain, yakni domain pengetahuan (kognitif), sikap dan perilaku (afeksi), dan keterampilan (psikomotorik). Implementasi dapat menggunakan strategi integratif-inklusif (disisipkan dalam mata pelajaran yang sudah ada) dan eksklusif (mata pelajaran khusus atau tersendiri). Model pendidikan antinarkoba yang integratif- 
inklusif, yaitu dengan alternatif materi anti-narkoba yang terintegrasi dalam mata pelajaran agama Islam pada kelas VIII SMP dan MTs semester 2, yang memuat Kompetensi Dasar (KD) yang secara eksplisit tentang pendidikan antinarkoba.

Model pendidikan antinarkoba yang integratif-inklusif dalam pendidikan agama Islam, secara aplikatif lebih berkedudukan sebagai pendekatan dalam pembelajaran. Hal tersebut akan tampak dalam desain atau Rencana Pembelajaran setiap mata pelajaran terpilih. Sebagai sebuah pendekatan pembelajaran maka implementasi pendidikan antinarkoba akan sangat tergantung dari kemampuan guru dalam melaksanakan kegiatan belajar-mengajar.

Metode pembelajaran Pendidikan Antinarkoba pada Kurikulum Pendidikan agama Islam adalah: 1) Ceramah dan penugasan; 2) Melibatkan peserta didik secara aktif dan kreatif dalam kegiatan pembelajaran; 3) Pemberian keteladanan; 4) Penelaahan berbagai modus operandi narkoba; 5) Studi kasus atau lapangan dan pemecahan masalah; 6) Pelatihan dan penyuluhan, dan 7) pelibatan siswa sebagai duta dan satgas antinarkoba.

Upaya pencegahan penggunaan narkoba bisa dilakukan dengan dua langkah, yaitu langkah preventif dan kuratif. Langkah preventif melalui pendidikan, dilakukan dengan cara internalisasi nilai-nilai antinarkoba terhadap peserta didik sebagai generasi penerus bangsa. Konsep pendidikan antinarkoba yang digagas sebagai solusi atas permasalahan bangsa adalah upaya mencegah berkembangnya peredaran narkoba pada anak bangsa Indonesia melalui pendidikan. Secara sederhana, langkah tersebut ditujukan untuk pemberdayaan peserta didik untuk Adapun Langkah represif dilakukan dengan cara menjalankan penegakan hukum yang tegas, pembinaan kepada pengguna dan hukuman oleh para aparat penegak hukum sehingga mencegah timbulnya penggunaan narkoba pada generasi muda bangsa.

Dalam manajemen pembelajaran semacam ini dapat dilakukan di semua mata pelajaran, baik agama maupun umum seperti mata pelajaran Pendidikan Jasmani Olahraga dan Kesehatan (PJOK), meliputi narkoba dan bahayanya, kesehatan reproduksi dan lainlain. Proses pembelajaran dapat dimulai dengan mengamati (observing) video yang menunjukkan fakta-fakta ilmiah, kemudian mengintegrasikannya dengan sains-al-Qur'an dan Hadits. Lagilagi, kemampuan semacam ini harus didukung dengan wawasan, 
bacaan, pengalaman, dan literatur memadai bagi guru yang melekat pada kompetensi pedagogik dan profesional.

Di ujung proses pembelajaran, pendidik secara bersama-sama menyimpulkan tentang sikap atau nilai. Maka, integrasi interkoneksi manajemen pembelajaran semacam ini akan menghasilkan peserta didik yang "berilmu amaliyah, beramal ilmiah, dan berakhlakul karimah".

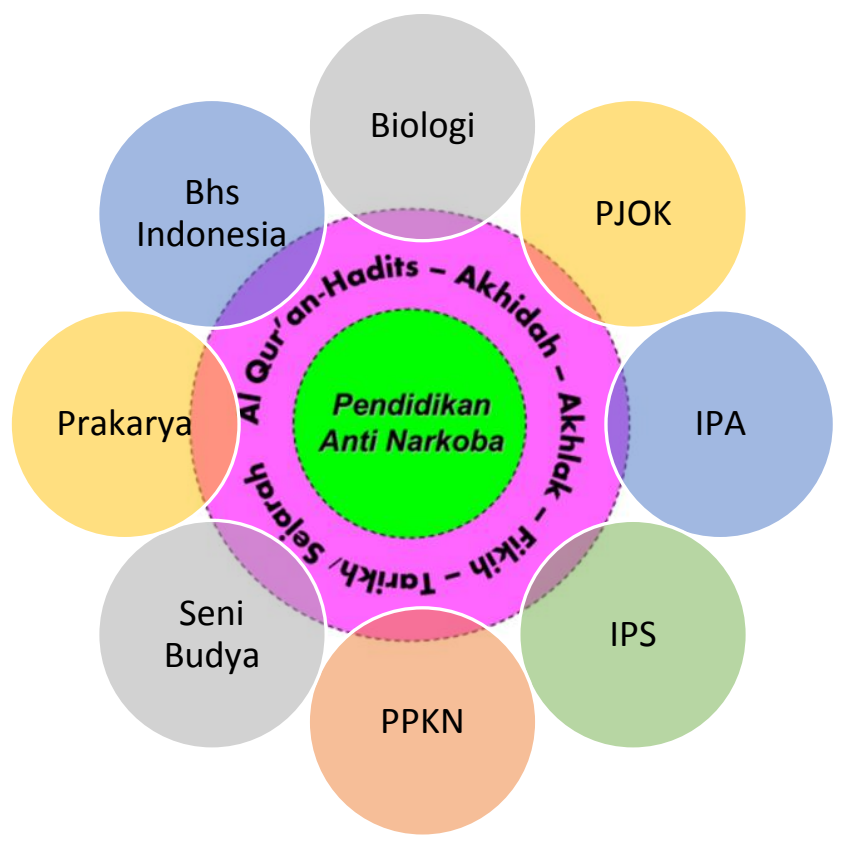

Gambar 1

Integrasi Pendidikan Anti Narkoba pada Kurikulum 2013

\section{G. Penutup}

Sebagai penutup pembahasan Integrasi Pendidikan Antinarkoba dalam Pendidikan Agama Islam dan Budi Pekerti Kurikulum 2013 adalah Materi Pendidikan Agama Islam dan Budi Pekerti dalam KI dan KD PAI kurikulum 2013 pendidikan antinarkoba sudah dimulai sejak SD, SMP dan SMA yang mencakup pengetahuan tentang narkoba dan bahayanya, peningkatan harga diri, dan pembentukan asertasi.

Pendidikan anti narkoba pada kurikulum Pendidikan Agama Islam dan Budi Pekerti diintegrasikan dengan mencakup tiga 
domain, yakni domain pengetahuan (kognitif), sikap dan perilaku (afeksi), dan keterampilan (psikomotorik).

Implementasi pendidikan antinarkoba di jenjang sekolah dapat menggunakan strategi integratif-inklusif (disisipkan dalam mata pelajaran yang sudah ada) dan eksklusif (mata pelajaran khusus atau tersendiri).

Manajemen pembelajaran pendidikan antinarkoba dapat diintegrasikan di semua mata pelajaran, baik agama maupun umum. Seperti mata pelajaran Pendidikan Jasmani Olahraga dan Kesehatan PJOK, meliputi tentang narkoba dan bahayanya, kesehatan reproduksi dan lainnya.

\section{Kepustakaan}

Tim Badan Narkotika Nasional, Materi Advokasi Pencegahan Penyalahgunaan Narkoba, (Jakarta: Badan Narkotika Nasional, 2005).

------, Materi Advokasi Pencegahan Narkoba, (Jakarta: Badan Narkotika Nasional, 2005).

------, Mencegah Lebih Baik Daripada Mengobati, (Bandung: Remaja Rosdakarya, 2007).

------, Pencegahan Penyalahgunaan Narkoba Berbasis Sekolah Melalui Program Anti Drugs Campaign Goes To School. (Jakarta: Badan Narkotika Nasional, 2008).

Tim Departemen Pendidikan Nasional, Rokok, Minuman Keras, dan Narkoba, (Jakarta: Pusat Pengembangan Kualitas Jasmani, 2000).

Tim Direktorat Jenderal Pendidikan Islam, Direktorat Pendidikan Agama Islam, Pedoman Umum Implementasi Kurikulum 2013, (Jakarta: Kementerian Agama RI, 2013).

Doll, Ronald C., Curriculum Improvemet Decision Making and Process, (Boston: Nallyn Bacon, 1996).

Good, Carter V. ed., Dictionary of Education, (New York: McGraw-Hill, 1996).

Jawa Post, Minggu 8 Februari 2015

Tim Kemendikbud. Kurikulum 2013, (Jakarta: Kementerian Pendidikan dan Kebudayaan Republik Indonesia, 2013). 
Machali, Imam, "Dimensi Kecerdasan Majemuk (Multiple Intellegences) dalam Kurikulum 2013", Insania, (Volume 19 Nomor 2/Juli-Desember 2014), hlm. 93-117.

-----, "Kebijakan Perubahan Kurikulum 2013 Dalam Menyongsong Indonesia Emas Tahun 2045", Jurnal Pendidikan Islam (Volume III No 1 Juni 2014/1345), hlm. 71-94.

Nasution, S., Pengembangan Kurikulum, (Bandung: Citra Aditya Bakti, 2003).

Oliva, Peter F., Developing the Curriculum, (New York: HarperCollins, 1992).

Peraturan Menteri Pendidikan dan Kebudayaan RI Nomor 81A Tahun 2013 Tentang tentang Implemetasi Kurikulum 2013.

Permendikbud No 57 tahun 2014 tentang Kurikulum SD

Permendikbud No 58 tahun 2014 tentang Kurikulum SMP/MTs

Permendikbud No 59 tahun 2014 tentang Kurikulum SMA/SMK/MA

Peraturan Pemerintah nomor 32 Tahun 2013 tentang Perubahan atas Peraturan Pemerintah Nomor 19 Tahun 2005 tentang Standar Nasional Pendidikan.

Sanjaya, Wina, Kurikulum dan Pembelajaran, (Jakarta: Kencana, 2008).

Soetopo, Hendyat dan Wasty Soemanto, Pembinaan dan Pengembangan Kurikulum, (Jakarta: Bina Aksara, 1986).

Spencer, Lyle M., Competence at Work: Models for Superior Performance, (Canada: John wiley \& Son, 1993).

Suara Karya, Jum'at 12 April 2013

Utami, Arini dkk, Katakan Tidak pada Narkoba: Mengenal Narkoba dan Bahayanya, (Bandung: Sarana Penunjang Pendidikan, 2006).

Undang-Undang RI Nomor 35 tahun 2009 tentang Narkotika.

Undang-Undang RI Nomor 20 tahun 2003 tentang Sistem Pendidikan Nasional. 
